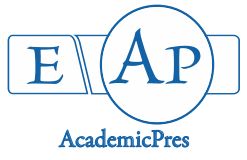

Costa TRS et al. (2021)

Notulae Scientia Biologicae 13(1):10880

DOI: $10.15835 / \mathrm{nsb} 13110880$

Research Article

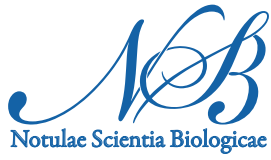

\title{
Physiological response of maize under different fertilization management under drought condition
}

\author{
Tayron R. S. COSTA, Matheus A. BORBA, José E. COSTA*, \\ Valéria F. O. SOUSA, Manoel B. ALBUQUERQUE, \\ Fábio MIELEZRSKI
}

\author{
Federal University of Paraíba, Agricultural Sciences Center, Rod. PB 079, 12, Areia, Paraíba, Brazil; tayron.r.s.costa@gmail.com; \\ andrade.borba95@gmail.com; costaeldo@gmail.com (*correspondingauthor); valeriafernandesbds@gmail.com; \\ bandeira1977@gmail.com;mfabioagro@gmail.com
}

\begin{abstract}
This work was aimed to evaluate the development of maize cultivated under different fertilization management, in order to establish an alternative for mineral fertilization. The experiment was carried out in the experimental area of Chã de Jardim, in Areia, Paraíba, Brazil. Six treatments were used with four replications. Plant height, stalk diameter, leaf number, chlorophyll a, b and total, photosynthetic rate, transpiration, stomatal conductance and internal $\mathrm{CO}_{2}$ concentration in the leaf were evaluated. In the 30 days after emergence, superiority of treatments was observed in the plants under chemical fertilization for plant height and number of leaves. For diameter of stalk the treatment organic fertilization $+\mathrm{P}$ and $\mathrm{K}$ showed superiority. At 60 days after planting the chemical fertilization provided the highest averages for plant height and stalk diameter. For the photosynthetic rate, transpiration and internal $\mathrm{CO}_{2}$ concentration, the treatment that presented the highest average was observed in plants under organic fertilization combined with $\mathrm{P}$ and $\mathrm{K}$ and $\mathrm{N}$ added in top-dressing. For the chlorophyll, the chemical fertilization provided the highest values. Organic fertilization in association with mineral fertilizers provided results close to those observed in mineral fertilization, being an alternative for nutritional management in maize.
\end{abstract}

Keywords: chlorophyll; organic; plant nutrition; transpiration; Zea mays L.

\section{Introduction}

Maize (Zea mays L.) is one of the most important crops worldwide and in Brazil (Almeida et al., 2020), the production in the 2018/2019 was estimated as 27,455.8 thousand tons, with national productivity of 5,379 $\mathrm{kg} \mathrm{ha}^{-1}$ (CONAB, 2019), which is below the United States productivity of $11,230 \mathrm{~kg} \mathrm{ha}^{-1}$ for this period (USDA, 2018). The Brazilian Northeast is the second region that participates least in the national production of this crop and it is also the region that has the lowest productivity which stands below $2,564 \mathrm{~kg} \mathrm{ha}^{-1}$ for the $2018 / 2019$ harvest. The Paraíba state presented one of the lowest productivities with an estimate of $513 \mathrm{~kg} \mathrm{ha}$ ${ }^{1}$ (CONAB, 2019).

Received: 11 Jan 2021. Received in revised form: 03 Mar 2021. Accepted: 04 Mar 2021. Published online: 05 Mar 2021.

From Volume 13, Issue 1, 2021, Notulae Scientia Biologicae journal will use article numbers in place of the traditional method of continuous pagination through the volume. 
In land use at the household level, the use of mineral fertilizers is greatly reduced due to the low purchasing power of small producers (Wiggins, 2014), as well as the risk of rainfall variability. It is also known that the continuous use of chemical fertilizers has resulted in negative results that are reflected in the rapid reduction of the organic matter content, salinization and erosion, resulting in scarcity of nutrient content in the soil (Tian et al., 2012; Smith et al., 2016).

Recently, due to environmental awareness the interest in sustainable agricultural practices has increased (Ardelean et al., 2012; Vastola et al., 2017). A practice commonly adopted to increase yield is the use of manure as an organic fertilizer for the supply of nutrients in the soil, which also provides physical improvements in the soil, such as increased infiltration, increased water storage capacity, higher aggregation of soil particles and reduction of erosive processes (Karami et al., 2012).

The organic fertilization seeks to bring positive effects, thus providing physical-chemical improvements in the soil when compared to mineral fertilization (Gomes et al., 2018). However, the use of nitrogen fertilizer also promotes maize yield gains in the first year of cultivation (Sui et al., 2018; Zhang et al., 2020). It is known that the residual effect of fertilization with animal manure acts in a significant way in the production of biomass in maize cultivation (Fan et al., 2020).

Therefore, the objective of this work was to evaluate the development of maize crop under different fertilization management, aiming to determine an alternative for mineral fertilization.

\section{Materials and Methods}

\section{Study site}

This work was carried out in the experimental area of Chã de Jardim, in the Agricultural Sciences Center of Federal University of Paraíba, located in Areia, Paraíba, Brazil, from June to October of 2017. This geographic micro-region called Brejo Paraibano has the climate classified as tropical humid, presenting average temperature of $22^{\circ} \mathrm{C}$ and the climate of the region is tropical and classified as Aw according Köppen, hot and humid with rainfall from autumn to winter, relative humidity of approximately $80 \%$ and rainfall of $1.400 \mathrm{~mm}$ annually (Ribeiro et al., 2018). The climatic data during the period of the experiment are presented in Figure 1 .

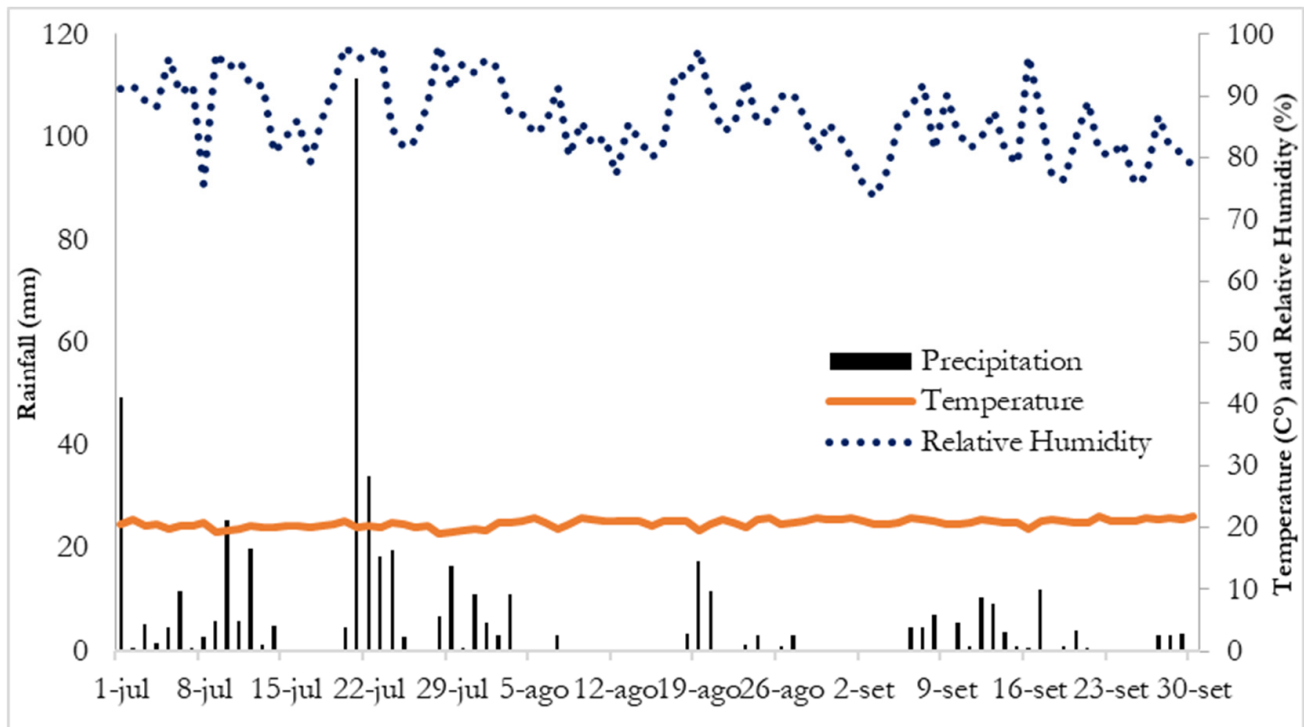

Figure 1. Rainfall, temperature and relative humidity at the Meteorological Station of the Agricultural Sciences Center, Federal University of Paraíba, Areia, Paraíba state, Brazil, during the experimental period 
The soil of the experimental area is Oxisol, of which chemical properties are presented in Table 1.

Table 1. Chemical properties of the soil, in the depths of $0-20 \mathrm{~cm}$

\begin{tabular}{|c|c|c|c|c|c|c|c|c|c|}
\hline $\mathrm{pH}$ & $\mathrm{P}$ & $\mathrm{K}$ & $\mathrm{Na}$ & $\mathrm{H}+\mathrm{Al}$ & $\mathrm{Al}$ & $\mathrm{Ca}$ & $\mathrm{Mg}$ & CEC & O.M. \\
\hline $\mathrm{In} \mathrm{KCl}$ & \multicolumn{2}{|c|}{$\mathrm{mg} \mathrm{dm}^{-3}$} & \multicolumn{6}{|c|}{$\mathrm{Cmol}_{\mathrm{c}} \mathrm{dm}^{-3}$} & $\mathrm{~g} \mathrm{~kg}^{-1}$ \\
\hline 4.8 & 2.40 & 28.40 & 0.05 & 5.49 & 0.10 & 0.81 & 0.30 & 6.72 & 36.72 \\
\hline
\end{tabular}

P and K Mehlich-1 extraction. SB: sum of bases. CEC: cation exchange capacity. OM: organic matter

\section{Experimental design and treatments}

The experimental design was complete randomized blocks (CRB), with six treatments (Table 2) and four replicates, totalling 24 experimental plots. Each plot consisted of five rows of five meters in length, with a spacing of $0.8 \mathrm{~m}$ between rows and 5 plants per row, totalling a population of 65,000 plants per hectare.

Table 2. Description of the treatments used in the experiment carried out in the experimental area of Chã de Jardim, Areia, Paraíba, Brazil

\begin{tabular}{|c|c|c|}
\hline Treatment & Composition & Treatment code \\
\hline T1 & No fertilization & NFE \\
\hline T2 & Chemical fertilization (NPK) & CF \\
\hline T3 & Organic fertilization & OF \\
\hline T4 & Organic fertilization + P and K & OF+TD \\
\hline T5 & Organic fertilization + N Top-dressing & OF+CF+TD \\
\hline T6 & Organic fertilization + P and K + N Top-dressing & \\
\hline
\end{tabular}

\section{Implementation and conduct of the experiment}

The fertilization was performed according to Cavalcanti (2008), based on the soil chemical properties (Table 1). In the whole experimental area, the soil acidity was corrected by the saturation method, aiming to raise the saturation to $60 \%$, for that the dolomitic limestone (PRNT 80\%) was used. The liming was performed 70 days before planting, then the incorporation of lime was performed at $0.20 \mathrm{~m}$ depth. Forty days before planting, a non-selective herbicide Roundup ${ }^{\circ}$, in doses of 1.51 / 1001 of water application was performed.

The application of the treatments was carried out in the rows of approximately $0.08 \mathrm{~m}$ depth in which fertilizers were applied and covered. Depth of seeding was $0.03 \mathrm{~m}$. Three seeds were sown every $0.2 \mathrm{~m}$ and after 10 days of the emergence (DAE) the thinning was performed, left each 1 plant per seed.

The 'Potiguar' (EMPARN', RN, Brazil) maize cultivar was used. Nutrients were provided with commercial sources: Potassium Chloride $(60 \% \mathrm{KCl})$; Urea (N 45\%); mono-ammonium-phosphate MAP (P2O5 48\%; N 12\%); and bovine manure as a source of organic fertilizer, chemical properties of the bovine manure have in your composition $15.58 \mathrm{~g} \mathrm{~N} \mathrm{~kg}^{-1}, 5.07 \mathrm{~g} \mathrm{P} \mathrm{kg}^{-1}$ and $11.82 \mathrm{~g} \mathrm{~K} \mathrm{~kg}^{-1}$.

\section{Parameter determinations}

For the biometric evaluation the following variables were evaluated: plant height (PH), Stalk diameter (SD) and the number of leaves (NL). To evaluate the gas exchange, the IRGA equipment (LI-6400XT LI$\mathrm{COR}^{\circ}$, Nebrasca, USA) was used to obtain the photosynthesis (A) rate, transpiration (E), stomatal conductance (gs) and internal carbon $(\mathrm{Ci})$. Chlorophyll data were obtained with the use of chlorophyll electronic metering equipment (ClorofiLOG-Falker ${ }^{\circ}$ ).

\section{Statistical analysis}

Data were tested for normality by the Shapiro-Wilk test, homogeneity of variances by the Bartlett test and analysis of variance by $\mathrm{F}$ test $(\mathrm{p} \leq 0.05)$ and the means were compared by the Tukey's test at $5 \%$ of probability, according to the criteria of Banzatto and Kronka (2011). All analyses were conducted in R software 3.6.3 (R Core Team, 2020). 


\section{Results and Discussion}

The different fertilization managements significantly interfered in the growth of maize plants, at plant height $(\mathrm{PH})$ the treatment no fertilization (NFE) was statistically inferior to the other treatments during the 30 and 60 days after emergence, probably due to the lack of nutritional demands necessary for this crop, while the greatest means were found with the use of chemical fertilization (CF), not differing from the treatments organic fertilization $(\mathrm{OF})$, organic fertilization $+\mathrm{P}$ and $\mathrm{K}(\mathrm{OF}+\mathrm{CF})$, organic fertilization $+\mathrm{N}$ Top- dressing $(\mathrm{OF}+\mathrm{TD})$ and organic fertilization $+\mathrm{P}$ and $\mathrm{K}+\mathrm{N}$ Top-dressing $(\mathrm{OF}+\mathrm{CF}+\mathrm{TD})$ for $\mathrm{PH}$ at $30 \mathrm{DAE}$ and $\mathrm{OF}+\mathrm{CF}+\mathrm{TD}$ for PH at $60 \mathrm{DAE}$ (Table 3).

Table 3. Plant height (PH), stalk diameter (SD) and the number of leaves (NL) of the corn cv. 'Potiguar' under different organic-mineral fertilization management evaluated at 30 and $60 \mathrm{DAE}$

\begin{tabular}{|c|c|c|c|}
\hline \multirow{2}{*}{ Treatments } & $\mathrm{PH}(\mathrm{cm})$ & $\mathrm{SD}(\mathrm{cm})$ & $\mathrm{NL}$ \\
\hline & \multicolumn{3}{|c|}{$30 \mathrm{DAE}$} \\
\hline NFE & $7.80 \mathrm{~b}$ & $0.62 \mathrm{c}$ & $4.05 c$ \\
\hline $\mathrm{CF}$ & $19.35 \mathrm{a}$ & $1.41 \mathrm{a}$ & $5.70 \mathrm{a}$ \\
\hline OF & $17.18 \mathrm{ab}$ & $1.25 \mathrm{ab}$ & $4.80 \mathrm{abc}$ \\
\hline $\mathrm{OF}+\mathrm{CF}$ & $18.70 \mathrm{a}$ & $1.36 \mathrm{a}$ & $5.20 \mathrm{ab}$ \\
\hline $\mathrm{OF}+\mathrm{TD}$ & $15.90 \mathrm{ab}$ & $1.19 \mathrm{~b}$ & $4.70 \mathrm{bc}$ \\
\hline \multirow[t]{2}{*}{$\mathrm{OF}+\mathrm{CF}+\mathrm{TD}$} & $19.40 \mathrm{a}$ & $1.39 \mathrm{a}$ & $5.25 \mathrm{ab}$ \\
\hline & \multicolumn{3}{|c|}{$60 \mathrm{DAE}$} \\
\hline NFE & $22.75 \mathrm{~d}$ & $1.72 \mathrm{c}$ & $6.80 \mathrm{~d}$ \\
\hline $\mathrm{CF}$ & $85.25 a$ & $2.43 a$ & $11.20 \mathrm{ab}$ \\
\hline OF & $66.95 \mathrm{c}$ & $2.27 \mathrm{ab}$ & $10.35 b c$ \\
\hline $\mathrm{OF}+\mathrm{CF}$ & $73.70 \mathrm{bc}$ & $2.30 \mathrm{ab}$ & $10.75 b c$ \\
\hline $\mathrm{OF}+\mathrm{TD}$ & $64.40 c$ & $2.24 \mathrm{~b}$ & $10.05 c$ \\
\hline $\mathrm{OF}+\mathrm{CF}+\mathrm{TD}$ & $79.85 \mathrm{ab}$ & $2.39 \mathrm{ab}$ & $11.75 \mathrm{a}$ \\
\hline
\end{tabular}

Means followed by the same letter in the column do not differ by the Tukey test at $5 \%$ probability

Therefore, the evaluation at $60 \mathrm{DAE}$ shows that there is variation in the efficiency of the management of fertilization for the height of corn, perhaps the addition of phosphorus and potassium together with organic compost and nitrogen fertilization in cover has contributed to the $\mathrm{PH}$ at $60 \mathrm{DAE}$ because it is a time that the plant needs high concentrations of N, P and $\mathrm{K}$. When the fertilizer dose is increased, the amount of nutrients available increases thus increasing corn plant height, up to a certain limit (Ullah et al., 2020).

Likewise, in the stem diameter (SD) the NFE treatment showed the lowest average and differed statistically from the others at 30 and $60 \mathrm{DAE}$, while the highest values were obtained in the CF treatment, probably due to the faster nutritional availability, however not differing from the OF, OF + CF and OF + CF + TD treatments at 30 and $60 \mathrm{DAE}$ (Table 3). Phosphate and nitrogen fertilization may have contributed to this result, since the nutritional requirements of nitrogen by the maize crop change with the different stages of plant development. In the initial stages these requirements are minimal and increase as the plant growth rate increases reaching its maximum during the flowering until the beginning of grain formation (Mansouri-Far et al., 2010).

While phosphorus is responsible for the development of roots and hence seedlings at the beginning of the plants' development, contributing to the increase of plant resistance for drought (Gouda et al., 2018). The soil initially had a low $\mathrm{P}$ content of $2.4 \mathrm{mg} \mathrm{dm}^{-3}$ (Table 1), together with this natural phosphorus deficiency and due to the high levels of oxides of iron and aluminum contained in the Oxisols, there could be a high adsorption capacity of this element.

Leaf emission at $30 \mathrm{DAE}$ was lower in the NFE and OF + TD treatments, with the highest incidences in the CF, OF, OF + CF and OF + CF + TD treatments (Table 4). At 60 DAE, the NFE treatment was 
statistically inferior to the others, with a greater number of leaves in the CF and OF $+\mathrm{CF}+\mathrm{TD}$ treatments. Increased organic fertilization with nitrogen fertilization in phosphate and potassium cover $(\mathrm{OF}+\mathrm{CF}+\mathrm{TD})$ obtained results similar to $\mathrm{CF}$, due to the addition of nutrients in the mineral form N, P and $\mathrm{K}$ to the organic input, which requires more time for mineralize the nutrients to a form assimilable by the plant, in relation to the nutrients provided by the mineral input.

The treatment that promoted the highest photosynthetic rate $(\mathrm{A})$ was $\mathrm{OF}+\mathrm{C}+\mathrm{TD}$, differing significantly from the OF treatment, with the lower photosynthetic rate (Table 4). This can be explained by the extraction of nitrogen from the maize. A higher nitrogen supply results in an increase in the rate of photosynthesis, leading to greater accumulation of biomass (Bender et al., 2013).

Table 4. Photosynthetic rate (A), transpiration (E), stomatal conductance (gs) and internal $\mathrm{CO}_{2}$ concentration $(\mathrm{Ci})$ in the leaf of maize 'Potiguar' under organo-mineral fertilization

\begin{tabular}{|c|c|c|c|c|}
\hline Treatment & $\begin{array}{c}\mathrm{A} \\
\mu \mathrm{mol} \mathrm{CO} \mathrm{m}^{-2} \mathrm{~s}^{-1}\end{array}$ & $\begin{array}{c}\mathrm{E} \\
\mathrm{mmol} \mathrm{H}_{2} \mathrm{O} \mathrm{m}^{-2} \mathrm{~s}^{-1}\end{array}$ & $\begin{array}{c}\mathrm{gs} \\
\mathrm{mmol} \mathrm{m}^{-2} \mathrm{~s}^{-1}\end{array}$ & $\begin{array}{c}\mathrm{Ci} \\
\mu \mathrm{mol} \mathrm{m}^{-2} \mathrm{~s}^{-1}\end{array}$ \\
\hline NFE & $24.19 \mathrm{ab}$ & $0.12 \mathrm{~b}$ & $130.44 \mathrm{a}$ & $3.08 \mathrm{a}$ \\
\hline CF & $27.12 \mathrm{ab}$ & $0.19 \mathrm{ab}$ & $137.31 \mathrm{a}$ & $4.11 \mathrm{ab}$ \\
\hline OF & $23.59 \mathrm{~b}$ & $0.13 \mathrm{~b}$ & $135.14 \mathrm{a}$ & $2.92 \mathrm{~b}$ \\
\hline OF+C & $24.05 \mathrm{ab}$ & $0.13 \mathrm{~b}$ & $132.50 \mathrm{a}$ & $3 . .13 \mathrm{~b}$ \\
\hline OF+TD & $26.37 \mathrm{ab}$ & $0.14 \mathrm{~b}$ & $131.57 \mathrm{a}$ & $3.41 \mathrm{~b}$ \\
\hline OF+C+TD & $29.07 \mathrm{a}$ & $0.23 \mathrm{a}$ & $137.30 \mathrm{a}$ & $4.90 \mathrm{a}$ \\
\hline
\end{tabular}

Means followed by the same letter in the column do not differ by the Tukey test at $5 \%$ probability

For the transpiration (E) a significant difference was observed, where the $\mathrm{OF}+\mathrm{C}+\mathrm{TD}$ treatment presented the highest values, not differing statistically from the treatment CF. It is probable that, the high transpiration rates to be associated with stomatal conductance. The $\mathrm{OF}+\mathrm{C}+\mathrm{TD}$ treatment had the highest transpiration rate, thus not differing from the CF, which is fundamental in the stomatal opening process, aggregated with the top-dressing with nitrogen, which is essential for the synthesis of proteins such as $\mathrm{H}^{+}$ATPase, that is used for the flow of $\mathrm{K}^{+}$and $\mathrm{Cl}^{-}$for the opening and closing of the stomata (Heidari and Jamshid, 2010).

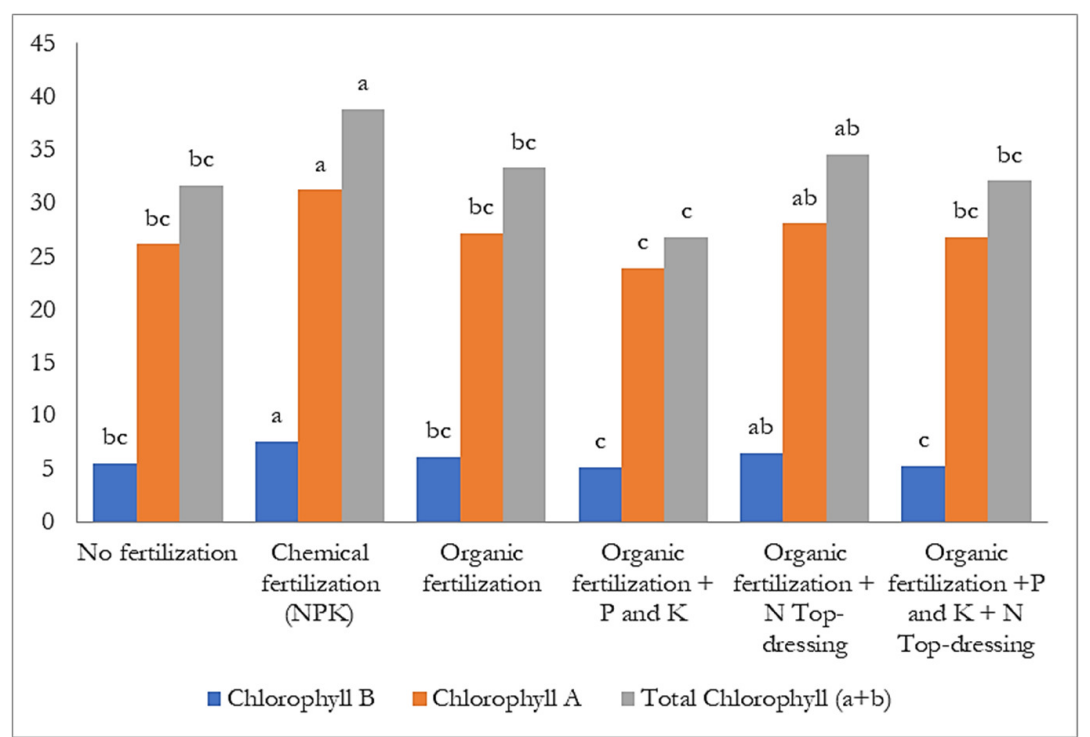

Figure 2. Falker Chlorophyll Index of the maize cv. 'Potiguar' under different fertilization management Means followed by the same letter in the series do not differ from each other by the Tukey test at $5 \%$ probability 
There was no significant difference for the stomatal conductance parameter (gs) among the treatments. The internal $\mathrm{CO}_{2}$ concentration in the leaf $(\mathrm{Ci})$ had a significant difference, with the highest values observed in the $\mathrm{OF}+\mathrm{C}+\mathrm{TD}$ treatment (Table 5). There was no significant difference in the stomatal gas conductance (gs) among the treatments, what is related to the water scarcity at critical periods of the crop (Figure 1). The plant in the stress condition tends to close its stomata in order to minimize water loss and maintain turgescence (Pinto et al., 2014).

Regarding the chlorophyll index, highest values were in the CF treatment, but no significant difference was observed from the treatment $\mathrm{OF}+\mathrm{TD}$ for chlorophylls $\mathrm{a}, \mathrm{b}$ and total. In general, the treatment with addition of phosphorus and potassium associated with the organic compound $(\mathrm{OF}+\mathrm{C})$ showed the lowest values for chlorophylls a, b and total (Figure 2).

\section{Conclusions}

The organic fertilization associated with mineral fertilization promoted results close to those observed for mineral fertilization, thus, being considered an alternative of nutritional management for the maize crop in the Brejo region conditions of the state of Paraíba. Organic fertilization along with the fertilization of $\mathrm{P}$ and $\mathrm{K}$ plus $\mathrm{N}$ in top-dressing promoted a great performance in the parameters evaluated.

\section{Authors' Contributions}

Conceptualization: FM and MAB; Data curation: MAB and TRSC; Formal analysis: MAB and JEC; Funding acquisition: FM and MBA; Investigation: MAB, JEC, VFOS and TRSC; Methodology: MAB and FM; Writing - original draft: TRSC, MAB and JEC; Writing - review and editing: FM, MBA, JEC and VFOS. All authors read and approved the final manuscript.

\section{Acknowledgements}

This work was supported by the Coordenação de Aperfeiçoamento de Pessoal de Nível Superior - Brasil (CAPES) - Finance Code 001.

\section{Conflict of Interests}

The authors declare that there are no conflicts of interest related to this article.

\section{References}

Almeida AF, Grangeiro LC, Ferreira NM, Gomes VEV, Silva SA, Lacerda RRA (2020). Phosphorus use efficiency by maize cultivars for the production of green ears. Revista Brasileira de Engenharia Agrícola e Ambiental 24(8):547-553. https://doi.org/10.1590/1807-1929/agriambi.v24n8p547-553

Ardelean M, Cordea M, Has V, Bors A (2012). Gx E interaction on yield stability of five sweet corn hybrids grown under different agricultural systems. Notulae Botanicae Horti Agrobotanici Cluj-Napoca 40(1):290292. https://doi.org/10.15835/nbha4017222

Banzatto DA, Kronka SN (2011). Experimentação agrícola [Agricultural experimentation]. Editora Funep (4th ed), Jaboticabal, SP, Brazil (in Portuguese). 
Bender RR, Haegele JW, Ruffo ML, Below FE (2013). Nutrient uptake, partitioning, and remobilization in modern, transgenic insect-protected maize hybrids. Agronomy Journal 105(1):161-170. https://doi.org/10.2134/agronj2012.0352

Booij R, Valenzuela JL, Aguilera C (2000). Determination of crop nitrogen status using non-invasive methods. In: Haverkort AJ, MacKerron DKL (Eds). Management of Nitrogen and Water in Potato Production. Wageningen Academic, Wageningen, Netherlands pp 72-82.

Cano FJ, Sharwood RE, Cousins AB, Ghannoum O (2019). The role of leaf width and conductance to $\mathrm{CO}_{2}$ in determining water use efficiency in $\mathrm{C}_{4}$ grasses. New Phytologist 223:12801295. https://doi.org/10.1111/nph.15920

Cavalcanti FJA (Coord.) (2008). Recomendações de adubação para o Estado de Pernambuco: 2. Aproximação [Fertilization recommendations for the State of Pernambuco: 2nd Approach]. Instituto Agronômico de Pernambuco, Recife, PE, Brazil, pp 212. (in Portuguese).

CONAB (2019). Companhia Nacional de Abastecimento. Acompanhamento de safra brasileira. Grãos. Safra 2018/2019. Monitoramento agrícola (in Portuguese). Brasília (6)4:75-80. Retrieved 2019 April 20 from https://www.conab.gov.br/info-agro/safras/graos

Crusciol CAC, Almeida DS, Alves CJ, Soratto RP, Krebsky EO, Spolidorio ES (2019). Can micronized sulfur in urea reduce ammoniacal nitrogen volatilization and improve maize grain yield?. Journal of Soil Science and Plant Nutrition 19:701-711. https://doi.org/10.1007/s42729-019-00070-7

Fan F, Zhang H, Alandia G, Luo L, Cui Z, Niu X, ... Zhang F (2020). Long-term effect of manure and mineral fertilizer application rate on maize yield and accumulated nutrients use efficiencies in North China Plain. Agronomy 10(9):1329. https://doi.org/10.3390/agronomy10091329

Gomes ETM, Berbara RLL, Pereira MG, Urquiaga SS, Tavares OCH, Assunção SA, ... García AC (2018). Effects of farmed managements in sandy soils on composition and stabilization of soil humic substances. Land Degradation \& Development 29:68-79. https://doi.org/10.1002/Idr.2839

Gouda S, Kerry RG, Das G, Paramithiotis S, Shin HS, Patra JK (2018). Revitalization of plant growth promoting rhizobacteria for sustainable development in agriculture. Microbiological Research 206:131-140. https://doi.org/10.1016/j.micres.2017.08.016

Heidari M, Jamshid P (2010). Interaction between salinity and potassium on grain yield, carbohydrate content and nutrient uptake in pearl millet. ARPN Journal of Agricultural and Biological Science, 5(6):39-46. Retrieved 2019 June 04 from http://eprints.icrisat.ac.in/id/eprint/1627

Karami A, Homaee M, Afzalinia S, Ruhipour H, Basirat S (2012). Organic resource management: Impacts on soil aggregate stability and other soil physico-chemical properties. Agriculture, Ecosystems \& Environment 148:2228. https://doi.org/10.1016/j.agee.2011.10.021

Li Q, Yang A, Wang Z, Roelcke M, Chen X, Zhang F, ... Liu X (2015). Effect of a new urease inhibitor on ammonia volatilization and nitrogen utilization in wheat in north and northwest China, Field Crops Research 175:96105. https://doi.org/10.1016/j.fcr.2015.02.005

Mansouri-Far C, Sanavy AMM, Saberali SF (2010). Maize yield response to deficit irrigation during low- sensitive growth stages and nitrogen rate under semi-arid climatic conditions. Agricultural Water Management 97:12-22. https://doi.org/10.1016/j.agwat.2009.08.003

Pinto H, Sharwood RE, Tissue DT, Ghannoum O (2014). Photosynthesis of $\mathrm{C}_{3}, \mathrm{C}_{3}-\mathrm{C}_{4}$, and $\mathrm{C}_{4}$ grasses at glacial $\mathrm{CO}_{2}$. Journal of Experimental Botany 65:3669-3681. https://doi.org/10.1093/jxb/eru155

Ribeiro JEDS, Barbosa AJS, Lopes SDF, Pereira WE, Albuquerque MBD (2018). Seasonal variation in gas exchange by plants of Erythroxylum simonis Plowman. Acta Botanica Brasilica 32:287-296. http://dx.doi.org/10.1590/0102-33062017abb0240

Smith P, House JI, Bustamante M, Sobocká J, Harper R, Genxing P, ... Pugh TAM (2016). Global change pressures on soils from land use and management. Global Change Biology 22(3):1008-1028. https://doi: 10.1111/gcb.13068

Sui J, Wang JD, Gong SH, Xu D, Zhang YQ, Qin QM (2018). Assessment of maize yield-increasing potential and optimum $\mathrm{N}$ level under mulched drip irrigation in the Northeast of China. Field Crop Research 215:132-139. https://doi.org/10.1016/j.fcr.2017.10.009

Tian H, Lu C, Melillo J, Ren W, Huang Y, Xu X, ... Pan S (2012). Food benefit and climate warming potential of nitrogen fertilizer uses in China. Environmental Research Letters 7:044020. https://doi:10.1088/17489326/7/4/044020 
Ullah R, Khan MJ, Muhammad D, Fahad S, Adnan M, Wahid F, ... Siddiqui MH (2020). Phosphorus nutrient management through synchronization of application methods and rates in wheat and maize crops. Plants 9(10):1389. https://doi.org/10.3390/plants9101389

USDA (2018). United States Department of Agriculture. World Agricultural Production, pp 29. Retrieved 2019 June 20 from https://www.fas.usda.gov/data/world-agricultural-production

Vastola A, Zdruli P, D’Amico M, Pappalardo G, Viccaro M, Napoli FD, ... Romano S (2017). A comparative multidimensional evaluation of conservation agriculture systems: A case study from a Mediterranean area of Southern Italy. Land Use Policy 68:326-333. https://doi.org/10.1016/j.landusepol.2017.07.034

Wiggins S (2014). African agricultural development: Lessons and challenges. Journal of Agricultural Economics 529-556. https://doi.org/10.1111/1477-9552.12075

Zhang G, Shen D, Xie R, Ming B, Hou P, Xue J, ... Li S (2020). Optimizing planting density to improve nitrogen use of super high-yield maize. Agronomy Journal 5:4147-4158. https://doi.org/10.1002/agj2.20334

OPEN ACCESS

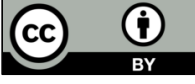

The journal offers free, immediate, and unrestricted access to peer-reviewed research and scholarly work. Users are allowed to read, download, copy, distribute, print, search, or link to the full texts of the articles, or use them for any other lawful purpose, without asking prior permission from the publisher or the author.

License - Articles published in Notulae Scientia Biologicae are Open-Access, distributed under the terms and conditions of the Creative Commons Attribution (CC BY 4.0) License.

(C) Articles by the authors; SHST, Cluj-Napoca, Romania. The journal allows the author(s) to hold the copyright/to retain publishing rights without restriction. 